\title{
Ética e Antropologia
}

SERGIO PAULO ROUANET*

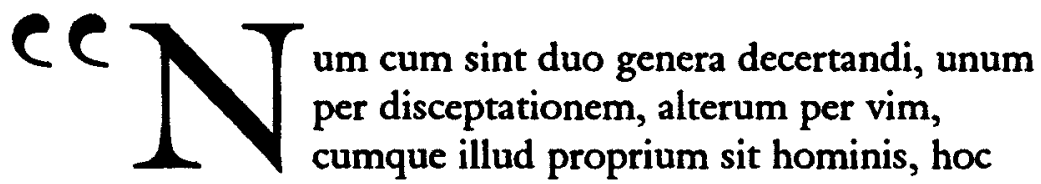

beluarum, confugiedum est ad posterius, si uti non licet superiore."

Cicero, De Officiis

"Wir haben beide

Uns unser Volk nicht auserlesen. Sind

Wir unser Volk Was heisst denn Volk?

Sind Christ und Jude eher Christ und Jude

Als Mensch? Ah! wenn ich einen mehr in Euch

Gefunden haette, dem es g'nuegt, ein Mensch

Zu heissen! "

\section{Lessing, Nathan der Weise"}

"Intellegendum etiam est duabus quasi nos a natura indutus esse personis; quarum una communis est ex eo, quod omnes participes sumus rationis praestantiaeque ejus, qua antecellimus bestiis, a qua omne honestum decorumque trahitur, et ex qua ratio inveniendi officii exquiritur, altera autem, quae proprie singulis est tributa "

Cicero, De Officiis

\section{I}

Há algum tempo, escrevi uma carta a Roberto Cardoso de Oliveira, pedindo-lhe algens dados sobre a questão do relativismo cultural $e$ ético na antropologia.

* Sérgio Paulo Rounanet é filósofo e sutor de As Razóes do Iluminismo (São Paulo, Companhia das Letras, 1988), entre outros livros. 
Para minha agradável surpresa, recebi uma resposta que excedia todas as minhas expectativas. Em vez de uma simples carta, Roberto mandou-me todo um ensaio, intitulado Ética e Saber, em que ele debate exaustivamente essa questão e muitas outras.

Em seu manuscrito de 25 páginas, o autor trata de temas como as condiçóes normativas do conhecimento científico; a problemática do relativismo na pesquisa antropológica; a antropologia como ciência social aplicada, particularmente nos processos de mudança social induzida; e o papel do Estado democrático na criação de um clima favorável à pesquisa científica.

Em todos esses temas, a ética é o foco principal. Roberto Cardoso se coloca na perspectiva da ética discursiva, de Habermas e Apel, e graças às suas categorias consegue esclarecer de modo original e pioneiro inúmeros aspectos da relação entre a ética e a antropologia.

Interpretei esse ensaio, cuja elaboração o autor atribui generosamente à minha consulta original, como um convite ao debate inter-disciplinar. Como antropólogo, Roberto recorre a uma moldura filosófica, e como filósofo, ou pelo menos como ensaista interessado em questōes filosóficas, seria minha vez de refletir sobre a antropologia.

O grande problema desse intercâmbio é que as condiçóes não são iguais. Roberto há anos se interessa por questóes filosóficas, particularmente as de caráter epistemológico, e eu não me considero sequer um auto-didata em antropologia.

Minha única credencial para participar do debate é justamente minha ignorância. Ela é tão radical, que pode por isso mesmo adquirir algum valor teórico: um olhar ingênuo pode por mero acaso ver coisas que talvez não fossem vistas por um olhar profissional. Imagino que em seus trabalhos de campo, Roberto tenha encontrado situaçóes semelhantes: um interlocutor indígena pode ocasionalmente fazer reflexóes válidas sobre a cultura branca, que não teriam ocorrido a quem vive nela.

De certo modo, estou na mesma situação. Em matéria de saber antropológico, sou um aborígene, que se relaciona com esse saber como o indígena se relaciona com o dogma da Imaculada Conceiçáo: com uma atitude de assombro e temor reverencial, que não exclui a possibilidade de uma ou outra observaçáo pertinente, capaz de interessar o missionário que o inicia no cristianismo. 
Encorajado por essa idéia consoladora, gostaria de responder ao convite de Roberto dizendo como vejo, a partir da mesma grade intelectual por ele adotada - a teoria da açáo comunicativa - a questáo do vínculo entre a ética e a antropologia.

Para facilitar a cómpreensão do leitor, não-familiarizado com os trabalhos de Habermas e Apel, começarei resumindo, muito esquematicamente, os princípios gerais da ética discursiva. Discutirei em seguida nos seguintes blocos temáticos a relação entre a ética $\mathrm{e} a$ antropologia: a ética e o saber antropológico, a ética e os processos de mudança social, e a ética como força motriz para promover a reversibilidade dos encontros interculturais.

\section{II}

$A$ validade da pretensão de veracidade só pode ser demonstrada pela consistência entre as palavras do interlocutor e os seus atos.
O ponto de partida da teoria da ação comunicativa é o mundo vivido (Lebenswelt): o lugar das relaçóes sociais espontâneas, das certezas pré-reflexivas, dos vínculos que nunca foram postos em dúvida. As relaçōes sociais que se dão no mundo vivido assumem, caracteristicamente, a forma da açáo comunicativa: um processo interativo, linguisticamente mediatizado, pelo qual os indivíduos coordenam seus projetos de ação e organizam suas ligaçóes recíprocas.

$\mathrm{Na}$ comunicaçáo normal invocamos sempre, implicitamente, pretensōes de validade (Gueltigkeitsansprueche) com relação a todos os enunciados. Quando falamos, estamos sempre asseverando, tacitamente, que nossas afirmaçóes sobre fatos e acontecimentos sáo verdadeiras, que a norma subjacente ao enunciado lingüístico é justa, e que a expressão dos nossos sentimentos é veraz. Na comunicaçăo que se dá no mundo vivido, as três pretensōes de validade se entrelaçam. $O$ processo comunicativo se vincula sempre a três "mundos": o mundo objetivo das coisas, com relaçăo ao qual cabem pretensóes de verdade (Wabrheitsansprüche); o mundo social das normas $e$ instituições, com relação às quais são invocadas pretensóes de justiça (Richtigkeitsanspriiche); e o mundo subjetivo das vivências e sentimentos, com relação ao qual se alegam pretensōes de veracidade (Wabrhaftigkeitsansprïche).

A coordenação comunicativa entre os interlocutores se dá através da expectativa de que se necessário cada interlocutor poderá justificar essas pretensóes de validade. A validade da pretensáo de veracidade só pode ser demonstrada pela consistência entre as palavras do interlocutor e os seus atos. Mas no caso das outras duas, ele precisará apresentar provas e argumentos - dentro de um quadro teórico geralmente aceito, no caso das proposiçóes descritivas, ou dentro de 
uma ordem normativa existente, no caso das proposiçóes prescritivas. Por exemplo, ele dirá que as primeiras são verdadeiras porque se apóiam numa teoria aceita sobre o mundo físico, e as segundas são corretas porque se apoiam numa norma vigente. A situação muda quando o que se contesta é a própria validade da teoria ou da norma. Sua problematizaçáo requer o adandono do mundo vivido e $o$ ingresso num tipo de argumentação sui generis. É o discurso.

As pretensóes de validade correspondentes à questóes cognitivas são problematizadas nos discursos teóricos, $\mathrm{e}$ as correspondentes à questōes normativas, nos discursos práticos. Nos dois casos, os participantes se distanciam do mundo vivido e assumem uma atitude crítico-hipotética de investigaçāo imparcial do que antes era visto como não-problemático. Nos dois casos, a argumentação discursiva tem como ponto de partida a suspensáo radical da crença na validade do que havia sido afirmado. Ela é posta entre parênteses, até que se conclua, pelo consenso, o processo de discussão discursiva, que pode levar à confirmação (mas também à negação) dos fatos apresentados como verdadeiros, e à justificaçáo (mas também à refutaçăo) das normas apresentadas como justas.

Nos dois discursos, é portanto o consenso que valida a proposiçăo, mas a validação só será conclusiva se o consenso for fundado. $O$ consenso será fundado se a argumentaçáo tiver sido conduzida segundo certos pressupostos pragmáticos, que incluem o de que todos os interessados tenham direito de participar do discurso, de que todos os participantes tenham iguais oportunidades de apresentar e refutar argumentos, de que todos os argumentos sejam submetidos ao livre exame de todos, de que nenhum dos participantes sofra qualquer coação, e outros. Esses pressupostos são os que prevalecem numa situaçáo lingüística ideal, para Habermas, ou numa comunidade argumentativa ideal, para Apel. São condiçōes ideais, porque raramente se atualizam em discursos concretos. Ao mesmo tempo, precisam ser pressupostas como reais, porque sem a expectativa de que elas estariam presentes, nenhum interessado participaria da argumentação.

Esses pressupostos estão na origem de qualquer argumentação, teórica ou prática. Eles remetem a valores morais, e nesse sentido podemos dizer que a ética é pressuposta por qualquer discurso. Mas as questōes normativas são debatidas nos discursos práticos. Contra o positivismo, a teoria da açáo comunicativa afirma que as proposiçóes normativas sáo tăo wabrheitsfachig, tão susceptíveis de serem falsas ou verdadeiras, como as proposiçōes descritivas. Como estas, as proposiçōes normativas são validadas por um consenso fundado. $O$ 
consenso em questóes práticas será fundado quando a argumentaçáo for conduzida segundo uma regra de procedimento derivada dos pressupostos pragmáticos de qualquer argumentaçăo, prática ou teórica. Essa regra é o princípio da universalização, o princípio U. É o seguinte o enunciado do princípio $U$ : "Todas as normas válidas precisam atender à condiçăo de que as consequências e efeitos colaterais que presumivelmente resultarão da observância geral dessa norma para a satisfaçăo dos interesses de cada indivíduo possam ser aceitas não coercitivamente por todos os envolvidos."

O princípio U pode ser fundamentado. Ele deriva dos pressupostos pragmáticos de toda e qualquer argumentação discursiva. Cada pessoa que ingressa num discurso prático se obriga intuitivamente a aceitar procedimentos que equivalem ao reconhecimento implícito do princípio U. Não posso, sem contradizer pressupostos gerais da comunicação, aceitar, na argumentaçăo moral, que alguns interessados sejam excluídos, que alguns participantes sejam coagidos, que outros não tenham a possibilidade de argumentar em defesa dos seus interesses, que outros se arroguem o direito de não seguir a norma.

A ética comunicativa é formalista, porque ela pressupóe que os conteúdos serão trazidos à moldura argumentativa pelos próprios interessados. Ao mesmo tempo, ela remete a uma ética material, encrustada nas estruturas formais da interação e do discurso. No nível da comunicação quotidiana há uma série de normas implícitas, como a que prescreve o respeito à integridade física de cada participante - a relação de violência é a antítese da relação comunicativa - a que prescreve a busca da verdade e da justiça, a que exprime a exigência da veracidade. No nível do discurso, a situaçáo lingüística ideal e seu derivado, o princípio $U$, prescrevem o tratamento igual de todos os participantes, a consideração dos interesses de cada um, a ausência de coaçáo, a inclusão de todos os interessados. Subjacente à camada normativa, existem vários valores fundamentais, vinculados a cada pretensão de validade e à propria exigência de inter-relacionamento através do nexo comunicativo. Todos esses valores podem ser expressos dicotomicamente, para que fique claro que correspondem a determinadas escolhas e preferências: o consenso é preferivel à violência, o saber é preferível ao não-saber, a veracidade é preferível à mentira, a igualdade é preferível à discriminação e a liberdade é preferível à coação.

A ética comunicativa é universalista. Ela se funda na hipótese de uma natureza humana universal, fundada na universalidade da comunicaçáo pela linguagem. A moldura argumentativa é igualmente universal, não no sentido de que náo existam discursos locais, em que os interessados 
abrangeriam apenas um grupo social especifico, mas no sentido de que os argumentos usados devem ser susceptíveis de convencer todos os seres racionais, mesmo os náo diretamente envolvidos. É o conceito kantiano da raesonierrende Oeffertlichkeit, uma comunidade argumentativa aberta, abrangendo tendencialmente a humanidade inteira. Universal, também, é o princípio $U$, versão comunicativa do imperativo categórico, cujo conteúdo é a exigência da universalização. Sem dúvida, o pleno desdobramento da competência discursiva, cujo princípio operacional é o princípio $U$, é mais fácil nas sociedades modernas, em que já amadureceram as condiçóes político-institucionais para a abertura de discursos problematizadores. Ao mesmo tempo, não é verdade que o processo discursivo seja exclusivo das sociedades modernas. Esse processo está pressuposto em toda e qualquer forma de comunicaçăo lingüística, independentemente de variaçōes espacio-temporais. Por menos modernas que sejam as formas de vida, não é possível imaginar uma interação comunicativa normal sem que as pretensōes de validade inerentes a tal comunicaçăo suscitem, mesmo embrionariamente, a necessidade de algum tipo de discurso. Ora, admitir a universalidade do discurso é admitir a universalidade do princípio $U$, pois sabemos que ele deriva necessariamente de pressupostos pragmático-lingüísticos sem os quais a argumentaçáo discursiva é impossível. Universais, enfim, são os valores materiais implícitos nas estruturas da interação e do discurso. Mesmo não sendo universalmente vigentes, são universalmente válidos, porque aderem às estruturas universais do entendimento pela linguagem (1).

\section{III}

Como toda ciência, a antropologia está sujeita à jurisdiçăo do discurso tebrico. Ela recolhe o seu material na observaçáo empírica, mas a validade dos enunciados relativos a tais observaçóes precisa ser posta à prova numa comunidade argumentativa de pares, e só depois de atingido o consenso esses enunciados podem ser considerados válidos. Se isso é verdade, já encontramos de saída um primeiro cruzamento entre a antropologia e a ética, como deixa muito claro o texto de Roberto Cardoso. Pois como qualquer discurso, o teórico se estrutura à luz dos pressupostos pragmáticos da argumentaçáo, e estes são em

(1) De Juergen Habermas, of. principalmente Vorbereitende Bemerkungen zu einer Theorie der komenumikatioe Kompeterte, em Theoric des Gesellschaft oder Sozialtechnologie

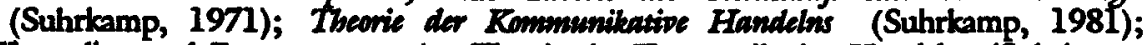

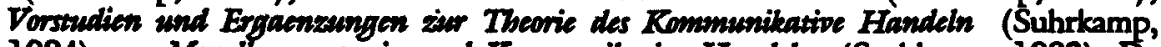

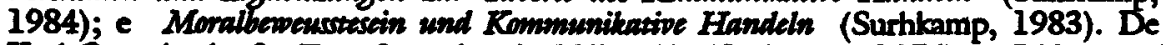
Karl-Otto Apel, of. Transformation des Pbilosophic (Surhkamp, 1976) e Disturers und Verantwortung (Suhrkamp, 1988). Vide mambém, do autor, Ética iluminists e ctica Aiscursion (Tempo Brasileiro, n. 98, julho-setembro de 1989). 
Esses pressupostos estâo na origem de qualquer argumentação, tebrica ou prática.

Eles remetem a valores morais, $e$ nesse sentido podemos dizer que a ética é

pressuposta por qualquer discurso.

sua essência de natureza ética. É uma ética argumentativa, com uma estrutura de normas e valores que privilegiam o entendimento mútuo $\mathrm{e}$ incluem valores como a liberdade de todos os participantes e igualdade de tratamento no decurso do processo argumentativo. Se a objetividade dos anunciados só pode ser testada num discurso teórico, a argumentaçáo conduzida nesse discurso só será válida se observar a ética argumentativa.

Nisso, a antropologia não difere de qualquer outra ciência. Em última análise, é num chāo normativo que brotam os enunciados cognitivos da antropologia.

Mas creio que podemos explorar mais a fundo a relaçáo entre o quadro comunicativo e o saber antropológico. Além de depender desse diálogó entre pares, não dependeria a validade desse saber, também, de um diálogo com seu próprio objeto de estudo - a cultrura que se quer conhecer?

Se o compreendi bem, Roberto Cardoso responde afirmativamente (2), mas sem se estender nesse aspecto do encontro intercultural. Ele examina primeiramente outro aspecto, em que o encontro funciona para promover a mudança social. Discutirei mais adiante esse tipo importantíssimo de argumentaçáo entre culturas, mas meu interesse no momento é epistêmico: a relaçăo entre o saber antropológico e a comunicação intercultural.

Penso que essa relaçáo é constitutiva da objetividade de tal saber. $O$ antropólogo năo se limita a estudar seu objeto com um olhar reificante análogo ao usado pelo cientista natural quando se relaciona com o mundo fisico, só então submetendo suas observaçōes à comunidade argumentativa dos pares; o próprio saber que ele apresenta aos pares se cristaliza dialogicamente, não pela observaçáo monológica do povo primitivo, mas por um processo interativo em que o horizonte do cientista $\mathrm{e} o$ dos indivíduos estudados tenderiam à aproximaçăo, sem chegarem jamais à fusão. Teríamos assim uma antropologia comunicativa, cuja objetividade é sobredeterminada por duas intersubjetividades: na origem a que se estabelece no diálogo com a cultura, e em seguida a que se estabelece no diálogo com a comunidade científica.

Mas antes de irmos adiante, é bom deixar claro que os dois processos comunicativos não são idênticos.

(2)" Cabe considerar que o exercício da logica do antropologo deveria ser confrontado com a lógica do natipo... Já que se dar espaço para a lógica do segundo por meio do estabelecimento de relaçōes dialógicas livres e simétricas". Roberto Cardoso de Oliveira, O saber e a trica (manuscrito) Pp. 12-13. 
A intersubjetividade do diálogo entre pares é simétrica, como ocorre no caso de qualquer ciência. Mas a outra, que a precede, é ambígüa, pois é ao mesmo tempo simétrica e assimétrica. Ela é simétrica, porque é regida por uma ética discursiva aplicável a todos os participantes .

Os pricípios básicos da argumentaçáo - liberdade e igualdade argumentativas - valeriam para todos. E é assimétrica, porque $O$ estatuto dos dois pólos é diferente. Graças à ética argumentativa, todos são sujeitos da argumentação; mas só alguns são objetos. A meta da argumentaçáo é obter conhecimentos válidos sobre a cultura de um dos dois pólos, e não sobre as duas culturas.

Mas nesse caso, só a relação comunicativa entre pares merece plenamente a denominação de discurso, pois este supóe a estrita simetria de estatuto entre todos os participantes. Reservaríamos o nome de quase-discurso para aquelas formas de comunicação em que a simetria é apenas parcial.

Reformulada, a tese seria entáo que a validade do saber antropológico é determinada por um discurso teórico entre pares, tendo como objeto um conhecimento obtido a partir de um quase-discurso, realizado entre o antropólogo e a comunidade estudada.

Esse quase-discurso seria naturalmente teórico, já que seus fins são cognitivos. Mas a matéria da argumentação incluiria questóes normativas, e não apenas questōes de fato. $O$ caráter desse discurso seria por isso estranhamente híbrido. $O$ antropólogo teria que ser tão "dual" como o quase-discurso de que ele participa. Se quiser levar a sério o seu papel dialógico, terá que entrar no jogo argumentativo, apresentando argumentos tanto em questōes de fato - a magia é ou não instrumentalmente eficaz, a feitiçaria pode ou não induzir à doença $\mathrm{e}$ à morte de uma pessoa? - como em questóes normativas e axiológicas - o infanticídio é ou não legítimo? Em questóes factuais o antropólogo se comportará como se estivesse num verdadeiro discurso teórico, e em questóes de legitimaçáo, sem em nenhum momento perder de vista seu interesse cognitivo, deverá entrar na argumentação sobre a validade das normas, exatamente como se estivesse num discurso prático. A hipótese subjacente a essa metodologia é que esse fogo cruzado de alegaçōes e refutaçóes acabe permitindo um conhecimento mais seguro da realidade que se quer pesquisar que o procedimento monológico habitual, pelo qual um informante se limita a responder perguntas, sem ser provocado a defender a validade de suas crenças culturais. 
Mas seria lícito recorrer à estratégia do quase-discurso? Afinal, toda a tradiçáo positivista e relativista da antropologia recomenda que o investigador ponha entre parênteses os seus próprios pontos de vista enquanto realiza a pesquisa. Ele deve ser wertfrei, abordar imparcialemnte seu objeto, sem deixar que os resultados da investigaçáo sejam afetados por sua própria escala de valores. Uma variante dessa atitude é o chamado relativismo metodológico, o procedimento pelo qual o pesquisador age como se todos os elementos da cultura fossem válidos, por mais que fora do contexto específico da pesquisa ele sustente uma opiniáo oposta. Presume-se assim que os preconceitos culturais do observador não interfiram com a objetividade da investigaçäo. Ora, o método do quase-discurso, longe de exigir o auto-cancelamento da subjetividade do antropólogo, impóe, pelo contrário, que ele exponha sem hesitar os seus próprios pontos de vista, participando ativamente da argumentação. Náo estaria comprometida, com isso, a objetividade da pesquisa?

É uma ética argumentativa, com uma

estrutura de normas e valores que privilegiam o entendimento mituo e incluem valores como a liberdade de todos os participantes e igualdade de tratamento no decurso do processo argumentativo.

Cumpre observar, preliminarmente, que a simples afirmaçáo de que os valores da "nossa" cultura devem ser desativados durante a observação não garante de modo algum que esse resultado seja alcançado. Todos sabemos que na prática nenhum observador consegue, realmente, deixar de avaliar, mesmo quando julga estar apenas descrevendo, e que nessa avaliação os preconceitos culturais, mesmo inconscientemente, desempenham um papel decisivo. $O$ relativismo metodológico se baseia numa ficçáo, e se expóe aos mesmos impasses do positivismo: agir como se todas as culturas fossem equivalentes e como se dentro da mesma cultura todos os elementos fossem válidos náo oferece nenhuma garantia de que na prática essa ficçáo possa manter-se.

Creio que a estratégia do quase-discurso nāo somente não afeta a objetividade da pesquisa como oferece perspectivas mais promissoras para evitar as distorçóes ețocêntricas.

Adotada a moldura comunicativa, $\mathrm{o}$ antropólogo atende à preocupação anti-etnocêntrica que está na raiz do positivismo e do relativismo: o mero fato de escolher a via da argumentação já mostra que ele está disposto, de saída, a abrir-se aos pontos de vista do seu interlocutor, em vez de impor despoticamente suas certezas culturais. Ao mesmo tempo, a teoria comunicativa não o confronta com a exigência impossível de abster-se de todos os juízos de valor, ingressando na argumentaçáo como um indivíduo fora da história e fora do espaço. Ele só pode participar da argumentaçáo, pelo contrário, se tiver opinióes, que podem ou náo ser condicionadas por circunstâncias de tempo e lugar, e se estiver disposto a defendê-las com argumentos 
racionais. Ele não pode aceitar a tese relativista de que todas as opinióes se equivalem, pois está convencido de que as suas são verdadeiras. Por outro lado, ele admite, como regra básica do "jogo de linguagem" da argumentaçáo, a possibilidade de que os argumentos do interlocutor venham a revelar-se mais convincentes, caso em que ele ajustará e reverá suas próprias conviç̧óes. Em suma, o investigador acredita na verdade, e por isso não é cético; mas aceita a hipótese de que seus interlocutores estejam mais próximos dela, e por isso náo é dogmático. $O$ debate livre e aberto das questóes factuais e normativas, em que o antropólogo expóe e revê suas opinióes, facilita a emergência de um saber teórico sobre todas essas questóes. Longe de ser bloqueada pela introduçăo no processo do ponto de vista do antropólogo, a objetividade desse saber $́$ assegurada, precisamente pela tomada de posiçáo do antropólogo no que se refere à validade das crenças cognitivas e à legitimidade das normas, porque ela estimulará seus interlocutores a definirem mais claramente as razóes pelas quais a comunidade as aceita.

Essa posição me parece conceitualmente correta, mas há evidentemente problemas de operacionalizaçăo e dificuldades em certos casos específicos. Um bom exemplo é dado pela investigação, feita por Vincent Crapanzano, de 21 racistas sul-africanos, mencionada no texto de Roberto Cardoso (3). Como aplicar o método dialógico a grupos cujos valores nos inspiram tal aversão que virtualmente excluem qualquer possibilidade de "fusăo de horizontes" ? Como dialogar com esses grupos, e com a sub-cultura dos SS, na Alemanha nazista?

Sem dúvida, o quadro comunicativo pode em si mesmo resolver parte desse problema. Como ele năo nos impóe nenhuma "postura relativizante", não precisamos sofrer nenhum dilaceramento existencial em nosso repúdio ao racismo. Não precisamos atender à exigência delirante dos relativistas de justificar, ou pelo menos abster-se de condenar, os campos de concentração e o apartheid, sob a alegaçáo de que tais práticas fazem sentido em suas respectivas culturas, do mesmo modo que a tolerância inter-racial faz sentido na nossa. A perspectiva comunicativa náo nos proíbe, antes nos impóe, a expressão dos nossos julgamentos de valor, nesses casos e em outros semelhantes. $O$ antropólogo comunicativo pode enlouquecer como qualquer outra pessoa, mas se ficar esquizofrênico certamente nảo será pela cisão de personalidade que se dá no antropólogo relativista, que por um lado adere aos valores universalistas dos direitos humanos $e$ por outro lado se sente obrigado por seu credo relativista a. "respeitar" a validade cultural das práticas que violem esses direitos.

(3) Roberto Cardoso de Oliveirn, ibidem, pp. 13-14. 
Não temos que respeitar coisa nenhuma, porque a atitude do "respeito" deriva da esfera do sagrado, onde não existe nenhuma argumentação; temos, isso sim, que tratar nossos interlocutores como seres racionais, capazes de argumentação, e a melhor maneira de prestar homenagem à dignidade humana desses seres racionais é incluí-los na esfera da argumentação, em vez de mantê-los num santuário extra-argumentativo, como os animais ameaçados de extinção.

Toda a questão, entretanto, está em saber se de fato é viável entrar numa relação argumentativa com certos grupos, como os afrikaaners de Crapanzano. Há limites para nossa capacidade de empatia com o ponto de vista do outro. Para isso há duas respostas.

Primeiro, nem sempre o quadro dialógico é possível, ou porque alguns grupos recusam, de todo, entrar numa relação argumentativa, ou porque o processo comunicativo, uma vez instaurado, não pode prosseguir devido a bloqueios internos que impedem a porosidade de uns aos argumentos dos outros. Se uma dessas condiçóes se verificar no caso dos racistas, o assunto está encerrado, e o antropólogo recorrerá a outras técnicas para fazer sua investigação.

Segundo, vale a pena tentar, apesar de tudo, e sempre que possível, a relaçáo argumentativa. Se os racistas aceitam argumentar, estáo demonstrando alguma disposiçáo de aceitar certas regras do jogo da argumentaçáo, como considerar o ponto de vista do outro, e não seria razoável que o antropólogo se mostrasse mais intransigente que os próprios afrikaaners, fechando-se à argumentação dos seus interlocutores. Náo prevejo, como resultado do quase-discurso instaurado, nem que os antropólogos se convertam ao racismo nem que os racistas se convençam da ilegitimidade do aphartheid. Mas se o diálogo não produziria qualquer aproximaçăo no que diz respeito à legitimidade do sistema normativo sul-africano, poderia produzir bons resultados do ponto de vista do conhecimento desse sistema. Afinal, nesse caso como no anterior, o quase-discurso seria teórico, vinculado a fins cognitivos, e sem nenhuma dúvida uma comunicaçáo que permitisse ao afrikaaner, estimulado pelos contra-argumentos do interlocutor, expor as razóes pelas quais considera legítima o apartheid, daria ao antropólogo valiosos elementos de informação sobre o lugar ocupado pelo racismo no sistema de crenças da cultura estudada, a relação entre essas crenças e o sistema socio-econômico etc.

Não gostaria de terminar este tópico antes de mecionar a curiosa analogia existente entre o método do quase-discurso e as entrevistas clínicas realizadas com crianças, segundo a metodologia de Piaget. Na 
entrevista clínica, o pesquisador conta uma historieta que culmina numa ação problemática por parte do personagem principal, e pede às crianças que tomem posiçáo quanto à legitimidade moral desse comportamento: estava certo ou errado, e por que? O interessante nessa técnica é que longe de limitar-se a registrar a resposta da rriança, o pesquisador instaura com ela uma verdadeira relação argumentativa. Ele discute os argumentos da criança, tenta refutá-los, procura convencê-la do ponto de vista oposto, chama atenção para certas implicaçōes colaterais da resposta dada, etc. A criança tem toda oportunidade de responder a esses contra-argumentos, e no fim do processo argumentativo o pesquisador chega a certas conclusóes sobre a maneira como a criança se relaciona com o sistema normativo, à luz do seu estágio de desenvolvimento psicogenético. Em outras palavras, foi conduzido um quase-discurso, porque é uma relação ao mesmo tempo simétrica, baseada na igualdade de direitos de todos os participantes enquanto sujeitos da argumentação, e assimétrica, devido à diferença de estatuto entre $o$ adulto que tem um objetivo cognitivo $e$ as crianças que são objetos do estudo; esse quase-discurso tem como substrato uma questão normativa; são debatidas questóes de legitimaçáo, como ocorre com os discursos práticos, e visam-se fins científicos, como ocorre com os discursos teóricos (4).

Voltando à ética, à guisa de conclusão, ela é duplamente determinante da objetividade do saber antropológico, porque é ela que fornece as regras de argumentaçáo tanto para o discurso teórico entre pares como para o quase-discurso que se estabelece com a cultura a ser estudada. Além de aparecer como pressuposto pragmático-transcendental de saber antropológico, a ética aparece como objeto desse saber, pois o sistema normativo e valorativo da cultura é precisamente um dos temas a serem investigados pelo quase-discurso.

\section{IV}

Abordarei agora a ética em sua relação com a antropologia aplicada, e mais especificamente com a açăo antropológica em processos de mudança social induzida.

A primeira questão ética que se coloca é saber se a mudança em si é desejável. Para alguns, seria anti-ético promover a mudança; para outros, seria anti-ético tomar partido pelo status quo.

Supondo afirmativa a resposta a essa questão, a segunda é definir eticamente o tipo de mudança que se deseja: qual seria a estratégia

(4) Bárbara Freitag, A moralidade infantil segundo Piaget - um estudo emptrico entre crianfas paulistas. em "Anuário de Educaçăo", Tempo Brasileiro, 1981. 
Além de aparecer como pressuposto pragmáticotranscendental de saber antropológico, $a$ ética aparece como objeto desse saber...

mais ética, a baseada na importação de modelos internos ou a que tenha como foco a autonomia e auto-determinação dos interessados?

O antropólogo comunicativo responde afirmativamente à primeira questão e escolhe na outra o segundo termo da disjuntiva. Sim, a mudança é necessária, desde que se observe o princípio da autonomia dos interessados.

A resposta afirmativa o coloca contra todas as concepçóes conservadoras, e em particular contra o tipo de conservadorismo que se manifesta em sua própria disciplina: o relativismo cultural. A opçáo pelo segundo termo da disjuntiva o coloca contra todas as formas de etnocentrismo. Contra os relativistas, ele diz sim à mudança, e contra a perspectiva atnocêntrica ele diz que a mudança tem que ser co-determinada pelos grupos envolvidos. Sua rota é clara, mas difícil: ele tem que se mover na passagem estreita que se estende entre os dois escolhos do relativismo e do etnocentrismo.

Nem todos os conservadores sáo relativistas, mas apesar de discrepâncias individuais podemos dizer que todo relativismo tende a posiçóes conservadoras. A afirmação de que não há princípios éticos universais, de que o que é válido numa cultura não é válido em outras, de que não há padrões de medida que permitam a uma cultura julgar outra, e outros ítens da vulgata relativista, derivam em linha reta do historismo alemão inspirado em Herder (5). Para o historismo, toda moral finca suas raízes no Volksgeist, e como cada povo tem o seu Geist, os valores são necessariamente múltiplos, únicos e incomensuráveis. Ora, esse historismo foi uma reação ideológica conservadora contra o tufăo universalista que soprava da França. Afirmando os valores da particularidade, os historistas estavam se defendendo da razão subversiva do Iluminismo, que queria refazer em toda parte a cidade dos homens, à luz de princípios universais de justiça.

Foi o mesmo esquema historista que levou Burke a repudiar a Revolução Francesa, invocando "the rights of the Englishman", produzidos pela história e portanto legítimos, em contraposição aos "droits de l'homme", universais e portanto abstratos (6). Foi o esquema que presidiu ao pensamento ultra-legitimista que se seguiu à Revolução, para o qual só existem homens particulares, e não o

(5) Der Herder, of. especialmente Auch eine Philosopbie der Geschichte (Berlin und Weimar, 1982) Herders Werke, III Band. Sobre o historismo em geral cf. Fr. Meinecke, Die Entstebung des Historismus (R. Oldenbour Verlag, 1965). O vínculo entre Herder e o pensamento antropológico foi reconhecido pelo próprio Boas, assim como por Kroeber, Lowie e Sapir.

(6) Edmund Burke, Reflections on the French Revolution (Penguin, 1988).

Estudos Avançados, 4(10) 
homem em geral, com a consequiência de que a Declaraçáo dos Direitos do Homem era vazia, porque não tinha destinatários concretos (7). Foi o esquema que impregnou a escola histórica alemá, para a qual só contam os valores "orgânicos", inseridos na particularidade da família e da nação. Foi o esquema do nazismo, que opunha a particularidade do "sangue e do solo" ao universalismo apátrida dos judeus cosmopolitas. É o esquema dos autoritarismos latino-americanos, que repudiam as "doutrinas exóticas", em nome da realidade nacional.

Ora, é também esse historismo que está na base do relativismo cultural. Também para ele todos os valores são situados e é também o genius loci que determina tudo o que a comunidade pensa e sente, com a diferença de que esse gênio não é mais o Volksgeist, mas o Kulturgeist. Agora é a cultura, e não a raça ou a nação, que define o horizonte do que pode ser visto e fornece todos os critérios de conhecimento e avaliaçáo. $O$ substrato romântico é o mesmo, e a carga conservadora não é muito diferente.

É preciso evitar mal-entendidos. Quando chamo de conservador o relativismo, não estou negando a imensa contribuiçáo dessa teoria para desmoralizar a arrogância etnocêntrica dos países avançados em seus contactos com outras culturas. Com isso, os relativistas contribuíram para solapar uma das bases ideológicas do imperialismo.

Talvez Kipling não tivesse criado o conceito do "white man's burden" se tivesse lido Boas. É possível que os franceses não tivessem tido tanta boa consciência em sua missão auto-imposta de civilizar a Argélia se tivessem aprendido com os antropólogos relativistas, que se os árabes eram menos avançados materialmente que os franceses, era porque o "cultural focus" da cultura francesa privilegiava o progresso material, e o da cultura árabe preferia outros valores, e o que nesse sentido nenhuma das duas culturas era mais civilizada que a outra. Talvez os ingleses não tivessem massacrado os aborígenes australianos se tivessem refletido, com os relativistas, que a sofisticaçāo do sistema do parentesco dessa cultura é tal, que desse ponto de vista são os ingleses que devem ser considerados povos primitivos. Se tivessem lido Malinowski e Radcliffe-Brown, é possível (ainda que pouco provável) que os missionários vitorianos, deslumbrados com a funcionalidade da poligamia e da poliandria, tivessem se abstido de impor aos povos que as praticavam os ritos matrimoniais da Igreja anglicana. Năo posso assegurar que no apogeu da influência

(7) Joseph de Maistre, Considfrations sur la France (Garnier, 1980). 
relativista, por volta dos anos vinte, os países metropolitanos tenham tido um comportamento mais virtuoso que no passado, mas pelo menos já nāo podiam ser imperialistas com boa consciência, o que náo é pouco. Esvaziado pelos relativistas o argumento da superioridade das culturas Ocidentais, o colonialismo tinha ficado mais nu que $o$ proverbial imperador de Andersen.

Se insisto, apesar de tudo, no viés conservador do relativismo, é porque seu ponto de vista favorece, de modo geral, o status quo social nas culturas não Ocidentais, $\mathrm{e}$ isso por duas vias, ambas radicadas no solo historista de onde deriva o relativismo cultural: a noção de que todos os critérios de julgamento moral se enraizam na cultura, e a noçáo correlata de que náo há possibilidade de avaliação inter-cultural.

Se não há princípios éticos que transcendam os preceitos sedimentados na cultura, é difícil imaginar a hipótese de um julgamento moral dos valores dessa cultura, à luz de princípios éticos que a ultrapassem. Com isso, é todo o projeto iluminista de descentramento com relaçáo aos valores da coletividade que está sendo questionado. $O$ privilégio máximo da modernidade, o de julgar criticamente a própria cultura, é privado de sua base teórica. Nisso, como em tudo mais, o relativismo revela suas raizes historistas e anti-iluministas, porque essa posição corresponde, ponto por ponto, à mais representativa das éticas historistas contemporâneas: a ética comunitária.

Para essa ética, não há princípios morais que ultrapassem os embutidos na comunidade. Como tantas outras variantes do pensamento conservador, essa ética surgiu como reaçáo ao perigosíssimo universalismo ético da Ilustração, com sua noção de que o individuo podia julgar sua própria sociedade à luz de critérios universais. A ética comunitária se defende dessa ameaça, regredindo a posições pré-iluministas semelhantes às da Antiguidade, para as quais a validade da moral não ia além dos limites do clâ ou da polis.

O paradigma é a crítica de Hegel à filosofia prática de Kant. Hegel opóe ao ponto de vista da Moralitaet, representado por Kant com sua teoria do imperativo categórico, e que supóe o distanciamento crítico do indivíduo com relaçáo às normas de sua sociedade, o ponto de vista da Sittlichkeit, que designa o lugar em que a razão ética já se realizou, não na interioridade de um sujeito ético mas em hábitos, costumes, instituiçóes, que fornecem critérios concretos, objetivos e duráveis para a fundamentação do comportamento moral (8).

(8) Cf. Moralitat und Sittlichkeit, ed. Wolfgang Kuhlmen (Suhrkamp, 1986). 
Todas as versóes subsequentes do pensamento moral conservador sáo variaçóes desse paradigma, de Comte, Durkheim e Parsons aos "neo-aristotélicos" alemães, para os quais o ponto de vista universalista da Moralitaet é anárquico e destrutivo de toda vida social (9).

Comum a todas essas variantes é o repúdio aos princípios universais da moralidade, e a idéia de que só a comunidade pode proporcionar princípios de julgamento moral. Substitua-se cultura por comunidade, e teremos, sem grandes alterações, o esquema historista básico subjacente ao pensamento moral dos antropólogos relativistas.

O mesmo esquema transparece na segunda tese relativista. Náo somente todos os valores e normas são exaustivamente determinados pela cultura, como eles só valem nela, e não podem ser estendidos a outras culturas. A consequência é que uma cultura não pode avaliar outra, porque náo há padrōes de medida comuns a ambas.

Essa tese é fundamental para o relativismo inspirado em Boas. Cada cultura é uma configuração única, resultante da confluência de dois fatores - a difusáo, pela qual certos traços culturais se disseminam de um ponto para outro, e a seletividade, pela qual a cultura integra essas contribuiçōes à luz de sua estrutura dominante de valores, rejeitando alguns elementos, acolhendo e re-elaborando outros. Esses dois fatores operam de maneira em grande parte aleatória, imprevisível, e portanto só por mero acaso uma cultura se parecerá com outra. Cada uma é um universo à parte, impenetrável aos outros (10).

A tese é menos rigorosa para os funcionalistas, porque há apesar de tudo um padráo de avaliação: a funcionalidade, medida por certos critérios que variam de autor para autor. Para Radcliffe-Brown o critério é a coesão e a estabilidade social: a religião é funcional porque sacraliza aqueles elementos da estrutura social sobre os quais se organiza a cultura, promovendo assim a coesão do grupo (11). Para Malinowski é a "redução da ansiedade" : a mágica é funcional porque

(9) Como representante dos neo-aristotélicos, vide Odo Marquard, Das Ueber-Wir em "Poetik und Hermeneutik", (W. Fink Verlag, 1984) n XI.

(10) Note-se que Boas jamais negou a unidade psíquica do gênero humano "emotions, intelect and will power of man are alike everywhere" - nem sequer a existência de várias semelhangas culturais nos povos mais diversos, atribuindo-as, entretanto, principalmente à difusão. Vide o capínulo The Unipersality of Cultural Traits, em The Mind of Primitive Man, (Macmillan, 1911).

(11) A.R. Radcliffe-Brown, Structure and Function in Primitive Society (Routledge and Kegan Paul, 1979), principalmente o capitulo IX, On the Concept of Function in Social Science. 
Se insisto, apesar de tudo, no viés conservador do relativismo, $e$ porque seu ponto de vista favorece, de modo geral, o status quo social nas culturas não Ocidentais... protege contra a angústia (12). Para Harris, é a adaptação ao meio físico - a guerra é funcional porque ajusta a populaçăo às possibilidades oferecidas pelo meio (13). Mas como essa funcionalidade não é aparente para os membros de outras culturas, pelo menos até que ela seja descoberta pelos especialistas, na prática a impenetrabilidade mútua das culturas é a mesma que para os boasianos.

Mas essa "suspensão de julgamento" se converte subrepticiamente em aprovaçáo apriorística. Em boa lógica, os boasianos teriam que limitar-se a dizer que não têm elementos para dizerem se uma cultura é ou não válida. Em vez disso, dizem que todas as culturas sáo igualmente válidas. Os funcionalistas poderiam julgar culturas ou traços culturais à luz de sua funcionalidade, mas em vez disso usam esse critério para justificar a posteriori o julgamento a priori de que essas culturas e esses traços são válidos. Para eles, qualquer aspecto da cultura, por mais estranho que seja, tem sempre uma funçāo. $O$ infanticídio, a vingança de sangue, a tortura, são sempre julgados funcionais, ou porque promovem a coesão social, ou porque reduzem a ansiedade ou porque têm conseqüências adaptativas. $O$ pressuposto invariável é que há sempre boas razóes para tudo o que existe. Não há muitos exemplos de algum traço da cultura que tenha sido declarado disfuncional.

A metamorfose da suspensáo de julgamento num julgamento positivo confirma a filiaçáo historista e traz à tona o parti-pris conservador. Nos dois casos, cada elemento da cultura é valido precisamente por ser um elemento da cultura. É a reformulaçáo, em linguagem antropológica, da frase hegeliana de que todo real é racional, que para qualquer conservador é um artigo de fé: o que existe provou seu direito a existir pelo mero fato de existir.

Esse a priori conservador leva a uma formulação conservadora do conceito de tolerância intercultural.

Para os funcionalistas, a tolerância se impóe porque se qualquer costume é em última análise, funcional, toda avaliação externa só poderia perturbar esse belo equilíbrio.

Para os boasianos, se todas as percepçōes, normas e instituiçóes são culturalmente condicionados, não há padrōes comuns de valor que autorizem uma cultura a criticar outra.

(12) Bronislaw Malinowski, Magic, Science and Religion (Doubleday, 1948), especialmente o capítulo IV, em que o autor discute a influência consoladora dos ritos públicos associados à morte, e o capítulo $\mathrm{V}$, dedicado à magia $\mathrm{e}$ ao "poder da fé".

(13) Marvin Harris, Cannibals and Kings: The Origins of cultures (Random House, 1977). 
Assim, o relativismo nos leva a aceitar "as new bases for tolerance the coexisting and equally valid patterns of life which mankind has created for itself from the raw materials of existence (14) (meus itálicos).

Para outro autor, "cultural relativism is a philosophy that recognizes the values set up by epery society to guide its own life and that understands their worth to those who live by them, though they may differ from one's own. Instead of underscoring differences from absolute norms that... are the product of a given time or place, the relativistic point of view brings into relief the validity of every set of norms for the people who have them, and the value these represent" (15) (meus itálicos).

As duas teses relativistas - a da determinação integral pela cultura e a incomensurabilidade das culturas - bloqueiam todas as vias para a mudança. A via endógena é bloqueada pela noçáo de que nenhum indivíduo, "culturalizado" por todos os poros e até a medula dos ossos, pode erguer-se contra os valores de sua cultura, por mais irracionais que sejam; a via externa é obstruída por um conceito de "tolerância" que impede qualquer diálogo transformador com essa cultura, por um lado impossível, porque a incompreensibilidade mútua impede qualquer acordo quanto ao que deva ser mudado, e por outro lado desnecessário, porque todas as normas existentes sáo perfeitas ab initio.

É óbvio que há um forte elemento de caricatura nessa descrição, porque a mudança social endógena é um fato empírico que não pode ser negado por ninguém - todos nós, relativistas ou não, temos que reconhecer que até as sociedades ditas "sem história" têm se modificado ao longo dos séculos - e porque os aportes externos são pressupostos pela própria lógica da difusão, sustentada pelos boasianos. Mas espero que meus amigos relativistas me concedam que a caricatura é suficientemente próxima da realidade para ter algum valor descritivo.

Depois da segunda guerra mundial, teve início uma forte reaçáo anti-relativista dentro da antropologia. Autores como Ralph Linton, Clyde Kluckhohn, Robert Redfield e Alfred Kroeber têm assinalado a falta de base empírica para a idéia de uma variedade infinita das normas e valores. Ao contrário, a observação etnográfica mostra a

(14) Ruth Benedict, Patterns of Culture (Houghton Mifflin Co., 1959), p. 278.

(15) Melville J. Herskovits, Cultural Relativism (Random House, Vintage Books, 1973) p. 31. 
existência de um certo número de invariantes culturais: atrás da multiplicidade aparente, existe uma uniformidade fundamental(16).

Em geral, as críticas ao relativismo têm se concentrado em suas dificuldades teóricas. Por exemplo, assinala-se que o relativismo cultural náo escapa ao dilema que está na raiz de todo relativismo: afirmar o relativismo é negar o relativismo, porque significa dizer que pelo menos uma tese - a relativista - não é relativa. É um argumento clássico, muitas vezes usado contra os céticos da variedade de Gorgias, Parmênides, Pirro, Bayle (17). No caso específico da antropologia, o paradoxo está em que o relativismo é uma atitude epistemológica típica da cultura Ocidental, pelo menos desde os sofistas, e que de modo algum existem nas próprias culturas primitivas, que em geral rejeitam os valores das outras culturas: ou seja, o etnocentrismo é na verdade um "universal", porque é partilhado por todas as culturas, e a atitude anti-etnocêntrica, advogada pelos relativistas, é ela própria etnocêntrica. Esses paradoxos são banais, e entediam cơm razão os filósofos profissionais. Mais séria é a crítica de que os relativistas operam em seu trabalho de campo com uma prática que contradiz sua teoria. Por mais que acreditem na singularidade absoluta de cada cultura, todos os antropólogos, relativistas ou não, partem da premissa tácita de que existe um hard core de traços invariantes, comuns a todos os homens, pois do contrário náo conseguiriam traduzir nas categorias de sua cultura as características da outra. Sem o pressuposto desse núcleo universal mínimo, os antropólogos náo começariam sequer a sua pesquisa, resignados de antemão a náo compreenderem uma alteridade indecifrável. Ora, não há notícia na história de um pesquisador que depois de ter recebido um "grant" da instituição financiadora competente, tenha voltado de mãos vazias, alegando que

(16) Depois de relacionar conceitos como a proibição do incesto e do homicídio, a proscriçăo da mentira, e ohrigaçóes mútuas entre pais e filhos, Clyde Kluckhohn diz que "these and many other moral concepts are thoroughly universal" , acrescentando a seguir que "while specific manifestations of human nature vary between cultures and between individuas in the same culture, human nature is universal". Ethical Relativity: sic ton, The Journal of Philosophe, 52, 1955. No mesmo artigo, Kluckhohn diz que Ralph Linton está " squarely in the mainstream of contemporary anthropological opinion" quando diz que "behind the seem endless diversity of culture patterns there is a fundamental uniformity". Segundo Roberto Cardoso, esse " mainstream" universalista estaria por sua vez sendo contestado hoje em dia, como se verifica na reaçāo "anti-antirelativista" de Clifford Goertz. Para uma visão de conjunto do tema do relativismo cultural na antropologia, vide Elvin Hatch, Culture and Morality (Columbia University Press, 1983).

(17) No artigo Reitcrations and Second Thoughts on Cultural Relativism (Relativism and the Study of Man) ed. Helmut Schoeck e James W. Wiggins, Eliseo Vivas se refere a esse argumento como "a armadilha de Epimênides" (p.53). 
a cultura que ele fora observar era tão única que não pudera compreendê-la (18).

Mas náo têm faltado, também, as críticas políticas. Logo depois da guerra, por exemplo, a guinada universalista foi alimentada pela indignaçáo moral provocada pelos crimes do nazismo: um padrão năo-relativo de julgamento foi considerado necessário para condenar essas atrocidades, qualquer que fosse o seu condicionamento cultural. Mas foi preciso esperar os anos 70 para que essa crítica política assumisse a forma que nos interessa agora: a de que o relativismo era intrinsecamente conservador.

Foi esse o foco da "radical anthropology". Embora marcada por uma atmosfera que hoje consideramos pouco atual - a da "new Left" vale a pena ainda ler a coletânea de ensaios contida no livro "Reinventing Anthropology", bem representativa dessa corrente. Para esses antropólogos, os relativistas partem de uma ideologia romântica, nostálgica, que idealiza, rousseauisticamente, os valores idílicos das culturas não-contaminadas pela civilizaçáo Ocidental. Ora, muitas dessas culturas, longe de serem paraísos bucólicos, são sociedades miseráveis e repressivas. Para preservar a pureza dessas culturas, 0 relativista se opóe à mudança social, muitas vezes contra o desejo expresso dos seus membros, que desejam, precisamente, aquelas inovaçōes detestadas pelos relativistas. Em nome da tolerância, estes acabam propondo, autoritariamente, um modelo que não é desejado pelos próprios interessados, e em nome do respeito à dignidade de todas as culturas, recomendam sua própria versão do apartheid: guetos e reservas, longe da infecçáo civilizada. Como diz um dos autores: "there is now some recognition that cultural relativism is logically incompatible with advocacy of socio-cultural change... Since relativism is applied only to aboriginal customs... relativism defines the good life for colored people differently than for white people, and the good colored man is the man of the bush" (19).

Posso ser mais sintético no que diz respeito ao segundo risco a ser evitado pela antropologia comunicativa - o etnocentrismo. Pois se essa atitude sobrevive entre alguns funcionários governamentais $\mathrm{e}$ internacionais, ela virtualemtne desapareceu da antropologia. Em

(18) Vide, sobre esse tema, Ernest Gellner, Relativism and Unipersals, em Rationality and Relativism (Ed. Martin Hollis e Steven Lukes), (The MIT Press, 1984), pg. 185. Cf. também a coletânea Rationality, ed. Bryan R. Wilson (Basil Blackwell, 1986), com várias contribuiçōes sobre a questão do relativismo em antropologia.

(19) William S. Willis, Jr., Skeletons in the Anthropological Closet, em Reinventig Antbropology, ed. Dell Hymes (Random House: 1972), pP.143-144. 
Além de não permitir pensar a mudança por vias endógenas, 0 relativismo não permite pensá-la através dos encontros interculturais. $A$ antropologia comunicativa não enfrenta a mesma dificuldade. grande parte, foi o mérito dos autores relativistas, como assinalei. Poucos se atreveriam, hoje em dia, a sustentar as teses evolucionistas de um Spencer, de um Taylor ou de um Morgan, para os quais a civilizaçáo Ocidental é a fase mais avançada do processo evolutivo, e portanto um modelo s ser visado por todos os outros povos. A hierarquização entre superior e inferior é portanto da essência do evolucionismo. Para ele, tanto no mundo físico como no biológico a tendência geral é a diferenciação do simples no complexo, do homogêneo no heterogêneo, o que implica a gradaçăo na escala das coisas e dos seres. No reino animal, o homo sapiens é superior aos outros seres vivos, e na espécie humana o europeu é superior às demais culturas: ele é mais inteligente, mais ético, mais apto a sobreviver segundo as exigências da seleção natural.

A mudança social é perfeitamente consistente com essas premissas eurocêntricas. Mas a lógica da superioridade européia determina o tipo de mundança considerado desejável: intrinsecamente inferior, a cultura exótica deve ser modificada segundo padrōes materiais e intelectuais válidos na Europa, a partir de uma ação induzida do exterior. A mudança é introduzida de fora, a partir de critérios exógenos, através de agentes externos, e no interesse da cultura hegemônica.

Diante da Cila do relativismo e da Caribdes do etnocentrismo, a antropologia comunicativa afirma duas coisas: (a) a mudança é necessária no caso de grupos materialmente carentes ou regidos por normas e instituições de caráter repressivo, e (b) ela deve ser conduzida de modo a levar plenamente em conta a autonomia das populaçóes interessadas.

A primeira afirmaçáo a leva a contestar as premissas que estáo na base da atitude relativista com relação à mudança.

A primeira dessas premissas, como vimos, é a do determinismo cultural, a tese de que o homem é de tal maneira impregnado pela cultura que não pode descentrar-se, constestanto os seus valores de base. Ora, do ponto de vista comunicativo o descentramento é uma conseqüência necessária da própria interaçăo, cuja problematização requer a entrada no discurso. A argumentaçáo moral suspende a validade dos contextos espontâneos de açáo e submete à crítica o sistema normativo e institucional. As evidências comunitárias são postas entre parênteses. O que era inquestionado se torna hipotético, as certezas culturais se tornam problemáticas. Com que direito, entretanto, o homem se julga habilitado a examinar criticamente a sua 
Lebenswelt - a sua "cultura" ? Com o direito que lhe é concedido pela própria forma de estrututraçáo da Lebenswelt. Ela é atravessada por processos comunicativos que repousam em pretensóes de validade, entre as quais a de caráter normativo. Quando pratico um ato lingüístico de caráter regulativo - ordem, proibição, recomendação estou pronto a justificar meu direito de praticar esse ato, se questionado por meu interlocutor. Na comunicação normal, se essa situação ocorrer farei essa justificaçáo alegando que estou obedecendo a uma norma intersubjetivamente aceita. Mas se a própria norma fôr contestada, esse argumento deixará de ser suficiente. Terei que ingressar num discurso prático, no qual todos os interessados porão à prova a validade da norma: é uma argumentação de segundo grau, em que a norma não serve mais como justificaçăo, pois é ela própria que precisa ser justificada. Mas se é assim, ao descentrar-se o homem não está contrariando a lógica da comunicação espontânea, mas levando-a às últimas conseqüências. Vale dizer que é a própria Lebenswelt que aponta além dos seus limites; é obedecendo à forma de organizaçáo comunicativa que rege a cultura que o homem se arroga o direito de avaliá-la. Em termos hegelianos, é a própria Sittlichkeit que me obriga a assumir o ponto de vista da Moralitaet - o do discurso.

Argumentando sobre a cultura, não estou fazendo mais que atender, num grau mais alto de reflexividade, à exigência de justificaçáo racional que permeia a argumentaçăo dentro da cultura. A teoria comunicativa não está afirmando, evidentemente, que todas as sociedades já alcançaram um estágio em que esse descentramento já esteja rotinizado. No Ocidente, ele só se iniciou com a Ilustração. $O$ que ela sustenta é que em toda parte essa virtualidade existe, pois não se trata de uma característica própria apenas à cultura Ocidental, e sim de um traço invariante que adere às estruturas universais da comunicação pela linguagem. Não me parece, como leigo, que a lógica argumentativa seja diversa em culturas "primitivas". As razóes invocadas para justificar um ato podem ser diferentes, mas são razóes. Quando um indígena alega que matou sua irmá porque ela violou um norma que prescreve a exogamia, está usando um argumento que talvez não fosse aceito no Ocidente, mas está usando um argumento, que por sua vez suscita contra-argumentos por parte do interlocutor, por exemplo argumentos de fato de que segundo certas testemunhas a moça teria sido violentada, em vez de unir-se voluntariamente ao cônjuge proibido pela cultura. Se a exigência da justificação racional se impóe dentro da comunicaçáo espontânea, admitida por todos a vigência da norma no caso, a norma da exogamia - podemos dizer que a cultura já contém, virtualmente, a possibilidade do passo seguinte, o uso da razão comunicativa para argumentar sobre a validade da própria norma - o discurso. Se em algumas culturas esse passo não é dado, não 
é porque ele seja excluído pelo "cultural focus" da cultura em questão, que ao contrário do Ocidente não privilegia o valor do entendimento argumentativo, mas simplesmente porque năo amadureceram ainda nessa sociedade as condiçóes sociais que permitam o pleno desdobramento da competência discursiva. No Ocidente, por exemplo, a atualizaçáo dessa competência é facilitada por instituiçōes democráticas e regras asseguradoras da liberdade de expressão que não existem necessariamente em toda parte. Mas em todas as culturas o discurso é o horizonte virtual dentro do qual se realiza a comunicação quotidiana, em que a exigência estrutural da justificação das pretensōes de validade já prevê, virtualiter, a possibilidade de que essa justificação não possa fazer-se dentro do sistema normativo existente. Mas nesse caso a submissão integral do homem à sua cultura, se ela realmente existe em certos casos, é uma situaçáo de fato, não de jure. Se em certas culturas o descentramento é impossível, é por razóes contigentes, que devem e podem ser modificadas, e não por razóes necessárias. A psicologia já demonstrou há muito tempo o que ainda não é claro para muitos antropólogos: que em todos os indivíduos existe uma progressão, condicionada pela faixa etária, que o leva de um estágio em que a moral comunitária é aceita como fundamento último do julgamento ético, para um último estágio, em que o homem julga segundo critérios gerais e abstratos que transcendem de todo a ordem social. As pesquisas inter-culturais provaram a validade dessa tese em todas as culturas, mas mostraram também que em algumas os valores culturais impóem uma regressão a estágios psicogeneticamente já ultrapassados. A cultura bloqueia aquelas estruturas de personalidade exigidas pela situação discursiva (20). Mas nesse caso é prestar um péssimo serviço às forças renovadoras que existem potencialmente dentro de cada cultura reforçar, pela abstenção ou pela aprovação tácita, como fazem os relativistas, as forças que inibem a atualização dessa competência. $O$ homem não pode viver fora da cultura, mas ela não é o seu destino, $e$ sim um meio para sua liberdade. Levar a sério a cultura não significa sacralizá-la e sim permitir que a exigência de problematização inerente à comunicaçáo que se dá na cultura se desenvolva até o telos do descentramento. Náo somos humanos fora da cultura, mas não seremos homens libres se nāo pudermos sempre que necessário assumir uma posiçáo de exterioridade com relaçáo ao mundo social.

Além de nảo permitir pensar a mudança por vias endógenas, o relativismo não permite pensá-la através dos encontros interculturais. A antropologia comunicativa não enfrenta a mesma dificuldade.

(20) Lawrence Kohlberg, Essays in Moral Development, vol.II, The Psychology of Moral Development, (Harper and Row, 1981). 
Uma das justificativas para essa atitude relativista é que não há padrōes comuns que permitam um acordo quanto ao conteúdo da mudança. A antropologia comunicativa afirma, pelo contrário, que a comunicação visando o entendimento mútuo é sempre possivel entre os homens, porque ela é inerente às próprias estruturas da linguagem. É evidente que o consenso é mais fácil entre interlocutores da mesma cultura, mas o núcleo mínimo de valores e traços invariantes capazes de facilitar esse consenso é comum a todos os homens, ainda que implicitamente: o próprio valor do entendimento mútuo, sem o qual não se abririam processos dialógicos, e os intrínsecos a cada pretensão de validade - o da verdade, o da justiça e o da veracidade. Uma vez ingressando na relação comunicativa, graças a esses valores comuns, os interlocutores podem por sua vez acercar-se cada vez mais, porque é inerente à comunicação o processo que George Herbert Mead (21) chamava o role taking, a capacidade de cada participante de colocar-se na situaçáo de vida e constelaçáo de interesses de todos os outros. Universalista, a ética comunicativa filia-se conscientemente ao universalismo da Ilustraçáo, e portanto acentua mais os fatores que unem os homens que os que os separam, e entre esses fatores está justamente a disposição universal para o entendimento lingüisticamente mediatizado. Os homens podem compreender-se, por maiores que sejam suas diferenças culturais, porque o telos da compreensão mutua é o princípio estruturador da comunicaçăo linguística, e porque o próprio processo comunicativo poderá remover os obstáculos culturais a essa compreensão. Os homens se comunicam porque são iguais e se tornam iguais porque se comunicam: é nessa circularidade que se funda a teoria comunicativa para refutar a noção historista de que existem trincheiras e barricadas culturais segregando os homens em universos autárquicos.

Outra justificativa para recusar a mudança pela via do confronto inter-cultural é que todas as culturas, e portanto também a que se pretende mudar, já sáo válidas a priori. A tentativa de mudança só poderia pertubar a soluçáo dada espontaneamente pela cultura para responder aos seus desafios de sobrevivência. É estranho que os antropólogos que dizem que todas as culturas são igualmente legítimas são em geral cidadáos liberais, que contraditoriamente com suas premissas não hesitam em criticar sua cultura de origem (com que direito, se todas as práticas dessa cultura, inclusive a que eles mais detestam, a do etnocentrismo, deveriam ser consideradas legítimas à luz dos postulados relativistas?) mas silenciam, pudicamente, diante de

(21) George Herbert Mead, Mind, Self and society. (The University of Chicago Press, 1974). 
aberrações nas culturas alheias que deveriam chocar sua consciência de eleitores do Partido Democrático ou Labour Party.

A antropologia comunicativa não tem essas inibições. Como ela dispõe de uma reserva de valores que não sáo culturalmente condicionados, que não são específicos da cultural Ocidental, que não são impenetráveis às diferentes culturas, ela não hesita em dizer que o conceito de tolerância que implica em considerar "igualmente válidas" as culturas que asseguram a sobrevivência material dos seus membros e aquelas em que grandes parcelas da populaçáo vivem em estado de pauperismo crônico é um conceito fraudulento de tolerância. Do mesmo modo, considerar "igualmente válidos" o parricídio e a benevolência com os mais velhos, a mutilação clitoridiana e a emancipação da mulher, o sacrifício ritual e o respeito aos direitos humanos, não é suspender o julgamento - é aprovar a prática injusta. Não é uma abstenção, e sim um voto a favor do status quo.

Na origem da atitude etnocêntrica está a intolerância Ela torna o diálogo imposstvel Na origem da atitude relativista está uma certa concepção de tolerância Ela toma o diálogo supérfluo.
A outra deformação combatida pela antropologia comunicativa - o etnocentrismo - é ainda mais intolerável. O relativismo, pelo menos, adere ao valor humanista da tolerância, por mais que ela seja vista de um modo equivocado. O etnocentrismo nega, de todo, ao povo "primitivo" a condiçáo de sujeito. Em vez de reforçar o status quo pela abstenção, ele o reforça pela intervenção. Em vez de idealizar a cultura alheia, ele a despreza. Em vez de ajudar a promover uma mudança emancipatória, reforça as heteronomias já existentes. Todo etnocentrismo é um particularismo. É a agressáo de uma cultura por outra, violando padrões universais de justiça.

Por isso, o antropólogo comunicativo critica, do mesmo modo que os relativistas, a arrogância dos evolucionistas do século 19 e o imperialismo que usou como álibi a teoria evolucionista. Mas o foco de sua crítica é outro. Os ingleses não eram universalistas demais, e sim de menos. Por não serem universalistas, exportaram para outros povos suas particularidades culturais, transformando num pseudo-universal o que na verdade se enraizava em caracterísiticas de tempo e lugar. É o esquema de todos os imperialismos: os valores metropolitanos são transformados, ideologicamente, em valores universais. Ora, o que há de errado nessa operação não é propor o universal como quadro de referência, e sim apresentar como universal o que de fato é particular, do mesmo modo que falso, na ideologia, não é afirmar a palidade universal de valores como a liberdade e a igualdade - eles sáo de fato universalmente válidos - e sim afirmar que esses valores já se tornaram universalmente pigentes. Contra essa agressáo particularista, a resposta é a liberatação pelo universal. $O$ etnocentrismo fere o valor universal do respeito à autonomia e à 
auto-determinação do homem, ou seja, viola o princípio básico de que todos os homens são sujeitos livres e iguais, condição universal, em qualquer tempo e em qualquer lugar, para que os indivíduos possam se comunicar, dentro da cultura e entre as culturas. $O$ relativista não tem esse recurso. Se é membro da cultura agredida, só pode defender-se invocando um saber próprio, uma normatividade local. A batalha se torna indecidível, porque sáo duas particularidades em conflito, sem arbitragem possível, pois não há escalas comuns às duas. A cultura agredida, se também relativista, só tem como recurso entricheirar-se em sua individualidade. Ela se torna etnocêntrica, do mesmo modo que o agressor, opondo ao particularismo outro particularismo, ou seja move-se em círculos, sem saída possível, no espaço particularista inventado pela cultura agressora.

Feita a partir desses pressupostos, a mudança é eticamente inaceitável. Ela não se faz com base num acordo, e sim com base na imposiçáo de modelos que náo foram objeto de qualquer argumentaçáo igualitária entre a cultura mudada e a que impóe a mudança.

Diante do mal-entendido relativista e da perversão etnocêntrica, o antropólogo comunicativo sente-se qualificado para julgar todas as práticas que violem a ética material subjacente às estruturas formais da comunicação pela linguagem: os valores universais do entendimento mútuo, da concórdia, da igualdade, da ausência de coaçáo, dentro da própria cultura e fora dela. Pois ele nem idealiza o Ocidente nem o critica a priori, nem transforma as culturas alheias em jardins do Éden nem as diaboliza.

Em conseqüência, ele denuncia como etnocêntricos tanto os missionários europeus que queriam evangelizar os chineses como os letrados confucianos que consideravam bárbara a cultura de onde vinham esses missionários. Ele dá razáo aos ingleses quando proibiram a prática indiana de queimar as viúvas na fogueira e os condena quando massacraram as populaçóes indígenas.

Em cada um desses exemplos, a crítica se faz a partir dos valores trans-culturais de tolerância, de liberdade, de ausência de discriminação: a imparcialidade do julgamento é garantida pelo caráter não-particularista do padrão de medida.

É verdade que opinióes desse tipo têm pouco valor se se limitam ao fôro íntimo de quem formula esses juízos. Ora, o quadro comunicativo nos impóe a intersubjetividade da argumentação. Todas essas opinióes sáo provisórias, enquanto náo forem postas à prova na relaçăo argumentativa. Elas são, num sentido etimológico, sem 
intenção pejorativa, "preconceitos" - opiniōes preliminares.

Esses pré-julgamentos não săo arbitrários, porque se baseiam em valores não-arbitrários, ao contrário dos preconceitos relativistas e eurocêntricos. Mas só deixatão de ser pré-julgamentos quando se converterem em julgamentos validados pela argumentação. É essa exigência que distingue a perspectiva comunicativa tanto da relativista como da etnocêntrica.

Esse é o nervo da questão: essas duas perspectivas excluem de todo a moldura comunicativa.

O etnocentrismo desqualifica ab initio, enquanto interlocutores, os membros da cultura considerada, porque eles sáo definidos de saída como inferiores e portanto incapazes de argumentação. $O$ relativismo opera a mesma desqualificação, seja porque o dialógo é impossível (não podemos compreender as culturas alheias) seja porque ele é redundante (já sabemos, antes de qualquer argumentaçáo, que tais culturas são válidas).

$\mathrm{Na}$ origem da atitude etnocêntrica está a intolerância. Ela torna o diálogo impossível. $\mathrm{Na}$ origem da atitude relativista está uma certa concepção de tolerância. Ela torna o diálogo supérfluo. Nos dois casos, nega-se o valor de base ética comunicativa, fixado por Kant para seu tempo e o nosso: o atingimento da maioridade (Muendigkeit), o uso da própria razão sem tutelas alheias (22). Em outras palavras, o ideal da maioridade é substituído pela estratégia da infantilização.

O etnocentrismo infantiliza os homens quando os declara intrinsecamente incapazes de argumentação.

O relativismo os infantiliza por uma concepçáo de tolerância que é o oposto da que foi recomendada pela Ilustração e que nessa forma é um dos valores básicos da consciência civilizada. A frase atribuída (incorretamente) a Voltaire, de que ele náo concordava com uma única palavra do interlocutor mas defenderia até a morte o seu direito de dizê-la, ilustra bem uma concepçáo de tolerância fundada em premissas comunicativas. $O$ autor da frase não dizia que todas as opinióes eram igualmente válidas; ele discordava das opinióes do interlocutor, acreditava pronfundamente que as suas eram mais verdadeiras, e estava disposto a defendê-las pela argumentaçáo, o que

(22) Immanuel Kant, Was ist dic Auftlaerung? em Gesammelte Sclbriften (Georg Reimer Verlag: 1912). 
supunha, como corolário, a liberdade de expressão integral para os dois participantes do processo comunicativo. A tolerância comunicativa supóe tratar todos os homens como adultos, com opiniōes que eles têm o direito de defender pela argumentação; a tolerância relativista implica em excluir do âmbito argumentativo os membros de certas culturas, infantilizando-os. Dizer a priori que todos os aspectos de uma cultura são legítimos dispensa seus integrantes de argumentarem a favor dessa legitimidade. Os

" nativos" sáo elogiados - sua cultura é válida a priori - e em seguida convidados a brincar em sua reserva ecológica.

Entre uma infantilização baseada no a priori de que certas culturas são inferiores e a baseada no a priori de que elas sáo portadoras de uma sabedoria espotânea (o mito da criança não-pervertida pelo mundo adulto é o correlato rigoroso do mito rousseauista do primitivo não-contaminado pela civilizaçáo) o antropólogo comunicativo recusa, de todo, a estratégia da infantilização. Todos os homens são ou devem tornar-se iguais, sim - alle Menschen werden Bureder - mas são iguais por serem dotados do atributo comunicativo por excelência, a Muendigkeit, que supóe o direito a capacidade de apresentar argumentos e de refutá-los.

Essas considerações permitem compreender a atitude da antropologia comunicativa com relação à mudança social induzida. Opondo-se ao relativismo puro, ela acredita que a mudança através do contacto inter-culțural é possível e desejável. A partir de suas premissas anti-etnocêntricas, ela só aceita esse contacto sob uma forma dialógica.

É exatamente a posição de Roberto Cardoso. Para ele, a mudança deve ser definida no interior de uma comunidade inter-cultural de argumentação. Sua inspiração é o conceito de etnodesenvolvimento, concebido como uma alternativa aos modelos ortodoxos de desenvolvimento elaborados por técnicos e funcionários governamentais e internacionais. 'Segundo a Declaração de San José, de 1981, o etnodesenvolvimento envolve o "fortalecimento da capacidade autônoma de decisáo de uma sociedade culturalmente diferenciada para orientar seu próprio desenvolvimento e o exercício da autodeterminação". Já é, implicitamente, a noção de comunidade argumentativa, pois só pelo diálogo poderăo os

"etnodesenvolvimentistas" compatibilizar seus objetivos profissionais com os princípios da autonomia e autodeterminação dos grupos interessados. É perfeita, portanto, a conclusão de Roberto Cardoso de que "o conceito de etnodesenvolvimento contém, ainda que subjacente, a idéia da existência de uma comunidade de argumentação, não mais inter-pares, porém entre grupos e indivíduos 
O grande mérito dessa regra, no caso dos confrontos inter-culturais, $\boldsymbol{e}$ que ela dá a palavra aos individuos concretos

portadores de culturas distintas... inseridos em situação inter-cultural".(23)

Qual o objetivo da mudança a ser promovida através dessa comunidade de argumentação? De novo, o conceito de etnodesenvolvimento dá uma resposta clara: o atendimento das necessidades sociais básicas. A comunidade inter-cultural definiria programas concretos para a melhoria das condiçóes materiais de vida da população.

Mas esse objetivo, por crucial que seja, não pode ser único. A mudança deve visar $o$ atendimento das necessidades materiais básicas, sem dúvida. Mas também visa aumentar os espaços de liberdade dentro da cultura, o que pode exigir, ainda que não necessariamente, a transformação da esfera normativa. Ora, aí aparece a primeira dificuldade com o conceito de etnodesenvolvimento. Pelo menos na formulaçáo de Stavenhagen, o etnodesenvolvimento implica uma tomada de posição prévia a favor da normatividade existente. A melhoria das condiçóes de vida deve ser promovida sempre que possível no interior da traćição. Como princípio geral, ele recomenda o uso e aproveitamento "das tradições culturais existentes". A hipótese de que essa tradição contenha momentos fundamentalmente repressivos, e que portanto eles estejam entre aqueles aspectos do sistema social que precisam ser mudados, não parece ter ocorrido a Stavenhagen. Como hispano-americano, a posição de Stavenhagen é compreeensível. Sua angústia com a descaracterizaçáo da cultura pré-colombiana pelos colonizadores espanhóis é legítima, mas esse exemplo é precisamente o paradigma típico-ideal daquela mudança heterônoma que a teoria comunicativa rejeita. Qual a objeção possível a uma mudança autônoma, determinada pelos próprios interessados, em diálogo, e não em competiçăo, com representantes de outras culturas?

Racionalmente, nenhuma. A objeção é feita por muitos autores, mas ela não é racional, porque deriva de uma ideologia e não de um argumento: a ideologia historista.

O historismo inverteu o vínculo do Iluminismo com a tradição. Para o Iluminismo, a tradição era a esfera por excelência da heteronomia, que submetia o homem à tutela do sagrado, impedindo-o de pensar por si mesmo. A bandeira mais alta do Iluminismo, o sapere aude kantiano, era um grito de guerra contra todos os elementos de poder ilegítimo

(23) Roberto Cardoso de Oliveira, op. cit, p.21.

Estudos Avançados, 4(10) 
encrustados na tradição. Essa era a essência da Idelogiekritik iluminista: desmascarar os dogmas e mitos pelos quais a tradição perpetuava a minoridade dos homens, sujeitando sua razão à tutela da autoridade. Pensar por si mesmo é libertar-se do préjugé - opiniăo sem julgamento, na definição de Voltaire - e a tarefa da tradiçăo é justamente a de fornecer opiniōes já prontas, que dispensem o homem da difícil tarefa de reflexão autônoma. O hostorismo reabilita a tradição, e ao fazê-lo re-sacraliza o mundo que o Iluminismo tinha secularizado. A tradiçáo não é mai aquilo do que devemos nos libertar, mas a matriz uterina que nos envolve do nascimento à morte e que não podemos descartar sem riscos individuais e coletivos. Somente dentro da tradição o homem é plenamente humano.

É a antítese da atitude comunicativa. Sem dúvida, é nos conteúdos semânticos da tradiçăo que nos abastecemos das interpretaçóes necessárias para a comunicação quotidiana, mas sua validade está permanentemente sub judice, e a todo momento está sujeita à investigação discursiva. Para a teoria comunicativa, a proposiçăo de que como princípio geral devemos respeitar a tradição é vazia de significado. Virtualmente, a ação comunicativa já é crítica da tradição, e essa virtualidade se atualiza sempre que ingressamos no discurso. Por outro lado, ela não se atualiza quando a força da tradiçáo é tão despótica que náo permite a abertura de discursos problematizadores.

Ela pode ser táo hegemônica em determinadas sociedades que bloqueia a própria percepção de que existe algo a problematizar. Foi a situação que prevaleceu antes da Ilustração e continua prevalecendo hoje em muitas sociedades. É nisso, tecnicamente, que consiste a ideologia: um sistema monolítico de representações, cuja função é inibir, pela falsa consciência que elas induzem, a instauração de processos discursivos. O discurso, cuja função é criticar a tradiçăo, é obstruído pela própria tradição. Longe de combater a Entzauberung iluminista, portanto, como fazem todos os historistas, a teoria comunicativa reivindica a Entzauberung como objeto do discurso e como condiçăo básica para a atualização da competência discursiva. Ela não levou a nenhuma "perda de sentido", Sinnverlust, como afirma Weber. Ao contrário, tendo emancipado o homem de um "sentido" imposto heteronomamente, a de-sacralização habilitou-o a fundar, em confronto dialógico com seus semelhantes, um novo horizonte de significaçōes.

Por isso não há por que não incluir, como segunda função da comunidade argumentativa, a crítica da tradição normativa. Crítica náo significa rejeição a priori: significa exame, e possivelmente 
validação da norma. Inserida numa comunidade inter-cultural, essa instância crítica terá caráter também inter-cultural. Mas pode contribuir para acelerar processos argumentativos internos à cultura a ser mudada, que dispensem com o tempo a cooperaçăo da outra cultura, ela pode facilitar a emergência e institucionalização dos processos discursivos que até então tinham permanecido embrionários por falta de estímulos externos. Um dos efeitos da mudança normativa inter-cultural seria então o de ajudar a cultura a atingir mais rapidamente o estágio em que a crítica interna da tradição se rotinize, passando da argumentaçáo dentro do sistema normativo existente à argumentação tendo esse sistema por objeto.

Nada disso assusta o antropólogo comunicativo. Tendo se libertado da autoridade do sagrado, ele não considera sacrílego o exame das normas e valores - ele escreve monografias sobre o tabu, mas não o pratica - e tendo concluído seu Édipo com relativo sucesso, não investe a esfera da tradiçăo com atributos maternos que a tornem invulnerável à crítica.

Isso posto, a comunidade argumentativa inter-cultural teria duas funçōes: a satisfação das necessidades básicas da população e a crítica seletiva das normas e valores. Conceitualmente separáveis, as duas funções se imbricam na mesma prática dialógica. Dialogando sobre os programas destinados à melhoria das condiçōes materiais de vida, os antropólogos (ou autores com uma visão antropológica) dialogariam também sobre o conteúdo e a validade das normas. Esse quadro dialógico único com duas funçóes entrelaçadas estaria sujeito aos princípios gerais da ética argumentativa: participação livre e igualitária de todos os interessados e livre exame por todos de todos os argumentos. Quando se discutissem especificamente questóes de legitimaçáo, as regras do princípio U serviriam como critérios pragmáticos para avaliar a validade de normas.

Recordo o enunciado do princípio $U$ : "Todas as normas válidas precisam atender à condição de que as consequiências e efeitos colaterais que presumivelmente resultarăo da observância geral dessas normas para a satisfação dos interesses de cada indivíduo possam ser aceitos năo-coercitivamente por todos os interessados".

O grande mérito dessa regra, no caso dos confrontos inter-culturais, é que ela dá a palavra aos indivíduos concretos que compóem a cultura, em vez de considerá-la como um bloco, que como tal é sempre "válido" ou "funcional". Estariam as vítimas de certas normas repressivas de acordo com esse julgamento? 
As normas que maltratam a mulher, por exemplo, têm como todas as outras uma razão de ser para os relativistas. Quando os árabes do Jordão matam uma mulher que ficou grávida fora do casamento, mesmo quando a gravidez se deve ao estupro, quando a mulher adúltera é assassinada pelo marido em certas regióes (a Calábria, digamos, para não ofender nossas susceptibilidades nacionais) ou quando a mulher indígena, na Vezenuela, é violada periodicamente por parte da tribo, o relativista diria que todas essas práticas são válidas, porque correspondem aos valores da cultura, e abster-se delas seria expor os indivíduos à desonra. A conclusáo implícita, $\mathrm{e}$ às vezes explícita, é que a própria mulher se sentiria infeliz se um bom samaritano tivesse tido a idéia etnocêntrica de acudi-la, como aquela personagem de Molière, que espancada pelo marido insulta seu salvador, indignada: "Et moi je veux qu'il me batte, moi!" Perfeito. $O$ uso do princípio $U$ poderia elucidar a questão. Pois essas normas só serão consideradas válidas se todos os interessados (e interessadas) participarem da argumentação; se nenhum deles (sem excetuar as mulheres) fôr coagido; e se nenhum participante (inclusive do sexo feminino ) rejeitar os efeitos da observância dessa norma para os interesses de cada um (e cada uma). Pessoalmente, acho improvável que o relativista encontre entre essas mulheres aliadas para a tese de que todas as soluçóes normativas encontradas pela cultura são igualmente válidas. Confesso que ficaria um pouco atônito se visse uma das participantes da argumentação reinvindicar seu direito cultural a ser espancada, brandindo convulsivamente um exemplar de Man and his Works, de Herskovits. Pode acontecer. Nesse caso, eu teria que imitar o benfeitor desastrado da comédia de Molière, depois que a mulher diz que faz questão de ser surrada pelo marido: "Ah! j'y consens de tout mon coeur!" (24).

Ingressando na argumentação normativa, $o$ antropólogo não está proibido de ter um pré-julgamento, baseado em seus pressupostos universalistas, sobre o conteúdo e a natureza da transformaçáo a ser estimulada. Ele não está proibido de achar indesejável um estado de coisas em que uma parte da populaçáo aterroriza a outra, por mais que seu treinamento funcionalista anterior o predisponha a admirar a sabedoria da cultura que resolveu de modo tão eficiente os seus problemas adaptativos.

Mas estaria sendo infiel aos seus pressupostos não-etnocêntricos se participasse de processos de transformaçáo com base exclusiva nesses pré-julgamentos. Eles só serão julgamentos válidos se não forem

(24) Molière, Le médecin malgré lui, Oeuvres Complètes (Nelson), vol.III, p.407. 
refutados por contra-argumentos convincentes por parte dos membros da cultura. O pré-julgamento se situa no início, não no fim do processo argumentativo.

Assim, o antropólogo apresentará argumentos contra uma norma que ele considere injusta - o infanticídio, por exemplo - e ouvirá contra-argumentos. Talvez alguns deles sejam apresentados por

"funcionalista" indígenas: sem essa norma, a sobrevivência material do grupo ficaria comprometida pelo excesso de população. Outros, mais bem informados sobre o que se passa na cultura "civilizada", comparariam o infanticídio à prática do aborto, tolerada no Ocidente ou reivindicada como direito legal. Como o encontro inter-cultural tem duas mãos, esses argumentos podem impressionar o antropólogo, levando-o a matizar seu pré-julgamento. Sem abdicar de sua conviç̧ão universalista do valor supremo da vida, em todas as latitudes, ele pode achar razoável, exatamente em nome do respeito à vida, o argumento de que a suspensão da norma criaria situaçōes de escassez que vitimariam milhares de pessoas. É claro que apesar disso ele alegaria que o primeiro vetor da comunidade argumentativa voltada para a cer uma relação comunicativa em que a cultura alheia figurasse como objeto, 0 antropologo estabeleceria uma relação cujo objeto seria sua própria cultura. mudança - o destinado a melhorar as condiçóes materiais de vida atenderia mais eficazmente a esse problema aumentando a produtividade da agricultura. Mas não deixaria de considerar racional o argumento do interlocutor. De resto, o próprio enunciado do princípio U o levaria a pesar as repercussóes a longo prazo da eliminação da norma; a cláusula de que os participantes precisam aceitar "as conseqüências e efeitos colaterais" da observância da norma, introduzida por Habermas para deixar claro que a ética discursiva é uma ética da responsabilidade, no sentido de Weber, e não uma ética da conviç̧áo, o forçaria a considerar a hipótese de que a norma em questão pode ser efetivamente funcional, medida por certos parâmetros.

Só resta lembrar, em conclusão, que por sua própria natureza a relação argumentativa exclui soluçóes impostas. Se a cultura nảo se convencer, de todo, dos argumentos apresentados, só cabe registrar a ausência de consenso e encerrar o exercício inter-cultural. Em qualquer hipótese, ele não terá sido inútil: a argumentação inter-cultural pode contribuir para desencadear processos argumentativos internos à cultura, levando-a a promover por seus próprios meios as mudanças materiais e normativas que ela considere apropriadas.

Subjacente a tudo o que foi dito até agora existe um leitmotiv incômodo, que certamente terá provocado no leitor um certo 
desconforto: o caráter parcialmente assimétrico da relação argumentativa. Por mais que se diga que todos os participantes sáo sujeitos da argumentação, a mesma igualdade de estatuto não se verifica quanto à matéria da argumentaçáo, que é unilateral. Tanto na argumentação teórica como na que visa a mudança, o objetivo é conhecer ou transformar uma das culturas, e não as duas. Nos dois casos, se todos são sujeitos - por isso a relação é simétrica - só alguns são objetos - por isso ela é assimétrica.

Sem dúvida, essa assimetria é atenuada pelo próprio caráter dialógico da relaçáo. Deixando-se permear pelos argumentos do interlocutor no quase-discurso teórico, o antropólogo aprende a conhecer melhor sua própria cultura, e ouvindo argumentos convincentes a favor da legitimidade das normas alheias, ele se dá conta do que precisa ser revisto em suas próprias normas.

Mas dito isto, continua sendo verdade que no tipo de confronto inter-cultural que examinamos até aqui, a intenção é o conhecimento e a transformaçăo do outro e não dos dois pólos da relação.

É uma situação indesejável. O encontro inter-cultural deveria ser capaz de funcionar nas duas direções. Presumivelmente é o que ocorre quando as duas culturas são equivalentes em poder e influência. Pode-se conceber que num encontro entre a cultura flamenga e a francófona, na Bélgica, o objetivo da reversibilidade não seja inacessível. O mesmo não acontece no gênero de confronto que estamos investigando. Pois aqui as duas culturas não são, simplesmente, iguais em poder.

A ética comunicativa não pode se esquecer dessa verdade elementar. Limitando-se a proclamar o princípio abstrato da igualdade de todos os sujeitos da argumentaçáo, ela estaria cometendo a mesma ingenuidade dos liberais, que depois de dizerem que todos os homens têm os direito de fundar um banco, se esquecem de que esse direito tem um sentido prático muito diferente para um bóia-fria e para um membro de família Rotschild. Um antropólogo pode estudar a cultura Navajo porque recebeu um financiamento da Fundação Ford, mas a cultura Navajo não tem como financiar um pesquisador nativo que deseje estudar a sub-cultura dos antropólogos da Universidade de Harvard. Nisso, importa pouco que a antropologia seja ou năo comunicativa. Nosso indígena poderia ter lido Habermas e estar disposto a ser paciente com seus objetos de estudo, evitando todo etnocentrismo, compreeendendo com grande delicadeza de 
sentimentós os dramàas e ànisiedades dos universitários ämericanos; ouvindo com' mưita aberturà os argumentốs dós séus intérlocutores sobre a validade de normas exóticas como ás quẹ réágém a ascénśnăo acadêmica e à competição éntre ós parés, é nada disso adiantaria muito: não básta querer ser dialógico parà ter a ooportunídade éfetivá de exercer uma ética dialógica.

Mas na falta de soluçăa mais satisfatóriá, essa dificuldáde póderia ser mitigada se o antropólógo dedicasse maiờ atençằo a éstüdàr suà " própria cultura. De alguma màneira, elè èstaria ássimì contribúindo para compensar a unilateralidade de sua maneira habitual de conceber o encontro entre as culturas, na quàl só à inidígená é objetó de investigação. Sabemós que não há grande nóvidade tisso,' pórque o foco "indigenista" há muito deixou de ser exclusivo na antrópólógia. Mas não estou 'me referindo aqui 'à aplicação dé técnicàs: antropológicas pảra o estudo das favelas, por exemplo, porque émíböra estas estejam inseridas núm meio ứrbanón, a relação entre essas comunidades "atrasadas" é o investigadór não seriá muito diferente da que este mantén com urna cultura primitiva. Penso no examé das : próprias instituiçōes : "civilizadas", "qué agóna seriam tratáás como se fossem as de uma sociedade indígena, com seus mitos, séus rituais, suas práticas econômicas e políticas, e seus sistemas de valores, muitos dos quais parecem pouco defensáveis à luz de princípios universais de justiça.

Mais uma vez o quadro comunicativo sereria áprópriado. De novo o antropólogo seria o pólo ativo da relação, com a diferença de que agora o "indígena" seria o próprio mémbro da cultura a que pertence o pesquisador: De novo, seria instaurado um quase-discurso teórico, ao cabo do qual seria obtido um sabér válido. Dé nóvo," haveria uma argumentaçáo prática visando à validaçáo das normas: De novo, a relação seria simétrica e assimétrica ao mesmo tempo, porque se por um lado todos seriam regidos pelos princípios da ética discursiva, pór outro lado o objetivo seria conhecer e transformár um dos pólos e não ambọos.

Qual seria o grupo a ser objeto dessa argumentação?

Náo excluo que seja a própria sociedadé global, considerada como um macro-agrupaménto. Há um estudo antropológico clássico sobre o . Japão que mostra a viablidade desse projeto (25). É claro qué nésse caso o diálogo náo poderia se dar no mesmo nível que o que se realiza com ưma comunidade péquena e pouco diferenciada, mas é

(25) Ruth Benedict, The Chrisanthanwan asid the Swörd (Róviledgé Paperbackś).

Estudos Avançádos, 4(10): 
exatamente o que se passa no discurso teórico entre pares. $O$ discurso teórico não é uma assembléia de sábios que se reúne para discutir uma teoria em torno de uma garrafa de sherry, como nas universidades inglesas. É uma comunidade sem contornos pessoais definidos, a raesonnierende Oeffentlichkeit de Kant, cujos membros não conhecemos obrigatoriamente e com que trocamos argumentos através de artigos, livros e conferências, e não necessariamente através de uma relação dialógica face a face. Seria essa a "outra cultura" com a qual estabeleceríamos a relação argumentativa, objeto de saber e avaliação, e náo mais co-participante de um exercício simétrico de validação.

Mas reconheço que a relação com interlocutores táo difusos teria algo de fantasmagórico. Seria menos insólito, à luz dos métodos de trabalhos habituais dos antropólogos, se a relação argumentativa se estabelecesse com grupos definidos dentro da sociedade moderna, pertencentes a subculturas específicas, como a dos técnicos, dos políticos, dos burocratas (como o autor deste artigo) e os cientistas, entre os quais os próprios antropólogos. Deve ser fascinante estudar os ritos de passagem desses grupos, seu sistema de representaçóes simbólicas, e sobretudo o seu repertório de mitos, entre os quais o mito da neutralidade do investigador e o da igual validade de todas as culturas.

Em suma, além de estabelecer uma relação comunicativa em que a cultura alheia figurasse como objeto, $o$ antropólogo estabeleceria uma relação cujo objeto seria sua própria cultura.

No primeiro caso, ele é um estrangeiro, que quer conhecer e avaliar a cultura alheia. Depois dos argumentos e contra-argumentos, haveria uma fusão tendencial de horizontes, nos dois níveis, graças à qual ele concluiria o julgamento teórico e a avaliação normativa.

No segundo caso, a posiçào do "estrangeiro" está vazia, e o antropólogo a ocupa. Ele se transforma num fórasteiro em sua cultura. Aliena-se, no sentido positivo da Verfremdung brechtiana, convertendo-se num alienigena, capaz de se surpreender com o que náo assombra ninguém, de fazer perguntas que ninguém faz, de perceber o que as evidências locais impedem que seja percebido. Ele é o estrangeiro de Kafka, que decifra no mais familiar a presença do mais enigmático.

Nesse mundo invertido em que é ó "indígena", representado pelo antropólogo, que conhece e avalia o civilizado, aquele assume o ponto de vista cultural do Outro e faz-se Outro em sua própria casa: Terminada a argumentação, há também uma aproximaçăo de 
... a ética esta na origem do saber antropologico, tanto no nivel da interaçio quase-discursiva entre o etnologo e a outra cultura como no nivel do discurso entre pares.

horizontes, como ocorreu no primeiro diálogò. Neste, o antropólogo era-realmente um estrangeiro, que termina por "compreender" o nativo, ássimilando-se parcialmente a ele; aqui, ele era um falso estrangeiro, que no final da argumentaçāo reeńcontra, modificada, sua identidade como cidadão da cultura de que èle tinhà se alienado.

São đúàs maneiras de descentrar-sé. Ele sai de si para conhecer o outro e sai de si para conhecer a si mesmo.

Com issó, ele ajuda as duas cultura a sè descentrarem também. Ele sé descentra nelas e elas nele. Terminada a argumentaçáo, cada uma das culturas fica menos particularista e mais aberta à compreensão recíproca:

Isto é evidente quanto à cultura alheia. $O$ antropólogo se abriu ào ponto de vista dessa cultura, mas o role taking funciona nas duas direçóes. Ouvindo os árgumentos do antropólogo em défesa dé súas convicçó́es, a cultura também se modifica. $O$ antropólogo deixou em parte de ser estrangeiro, mas a cultura deixou em parte de ser nativa.

No caso da cultura Ocidental, o descentramento é duplo. Através do primeiro processo dialógico - o que tem por objeto a cultura alheia ela sé expatria, nó seritido geográfico. Ela viaja para outro solo e desfaz-se em parte de suas certezas. Através do segundo processo dialógico - aquele em que ela é objeto - ela viaja dentro de si mésma. Ela se cinde em dois, desdobra-se numa instância que vê, dotada de um olhar estrangeiro - o olhar etnográfico - e outra instância que é vista, objetó de saber, de crítica e de desmascaramento. Graças a isso, ela se percebe em toda a sua contigência, em toda a pobreza do seu particularismo. Ela acede à perspectiva do Outro é de todós os Outros que integram a comunidade inter-cultural do gênero humano.

Sáo as duas modalidades clássicas de descentramento adotadas pela Europa desde $o$ início dos tempos modernos. O europeu se descentra quando viaja para outros países e quando representantes de outras culturas viajam à Europa. Ele aprende quando vai ao Outro e quando - Outro vem até ele. Nesse aprendizado, ele se desprende dos seus preconceitos locais e ascende ao plano universal.

O mais belo exemplo do descentramento do primeiro tipo é o proposto por Rousseau. Numà notá do Discours sur l'Inégalité, ele recomenda que em vez de permanecerem confinados em seu país natal, os homens viajam ao encontro de outros povos, "secoulant le joug de leurs préjugés nationiaux", a fim de "apprendre à connaître les hommes par leurs conformités et leur différences, et acquérir cés

Estudos Avançidós; 4(10) 
connaissances universelles qui ne sont point celles d'un siècle et d'un pays exclusivemment, mais qui, étant de tous les temps et de tous les lieux, sont pour ainsi dire la science commune des sages" (26). $O$ sábio não viaja para comprovar a tese relativista de que suas opiniōes e as alheias são todas igualmente válidas, mas para alcançar, "sacudindo o jugo dos seus preconceitos nacionais" , um saber que não seja o de "um século e de um país exclusivamente", mas que pertence "a todos os tempos e todos os lugares".

O segundo descentramento ocorre quando o estrangeiro visita a Europa. Desde Montaigne, é um tema clássico da literatura Ocidental.

Em seu famoso capítulo dos Cannibales, nos Ensaios, Montaigne descreve um índio brasileiro que visitara a França no tempo de Henrique IV. Montaigne se deslumbra com a lucidez desse selvagem, com a justeza do seu julgamento, com sua alta moralidade. $O$ índio observa tudo e comenta tudo o que vê, relativizando todas as instituiçōes européias à luz dos critéiros universais do direito da natureza, que é o de sua cultura. Marxista apant la lettre, esse contemporâneo de Villegaignon declara que em toda parte tinha "apperçue qu'il y avait parmi nous des hommes pleins te gorgez de toutes sortes de commoditez, et que leurs moitiez estoient meddinas à leurs portes, décharnez de faim et de pauvreté; et trouvoient estrange como ces moitiez icy necessiteuses pouvoint souffrir une telle injustice, qu'ils ne prinsent les autres à la gorge, ou missent le feu à leur. maison" (27).

Montesquieu usa a mesma técnica nas Cartas Persas. Dois persas, Rica e Usbek, visitam a França da Regência, e zombam das normas e costumes da Europa, relativizando-as e mostrando seu lado particularista, à luz das normas invariáveis do direito natural (28).

Voltaire tratou em pelo menos duas ocasiōes o topos do estrangeiro lúcido, em Micromégas, quando um habitante de Sirius visita a Terra, e no Ingénu, em que um hurăo norte-americano viaja para a França. Também aqui à perspectiva é a universalista. Náo se trata de mostrar

(26) Jean Jacques Rousseau, Discours de I Ṭnegalitt parmi les hommes, (Garnier, 1960), p.111. Há três livros clássicos sobre a influência das viagens aos países exóticos na mentalidade européia: Geoffroy Atkinson, Les relations de poyages au 17 tme siècle et $l$ 'toolution des idtes (Lib. Ed. Champion, s.d.); Gilbert Chinard, L'Amtrique et le rête exotique dans la litttrature franfaise au 17 tme ot $182 m e$ siecle, Slatkine Reprints, 1970; e Pierre Martino, $L$ Orient davis la littrature frangaise au 172 me at $182 m e$ sizcle, Slatkine Reprints, 1970.

(27) Montaigne, Essais, Oeutres Complètes, Pléiade, (Gallimard, 1962), p.213.

(28) Montesquieu, - Letrres Persanes', Ocurres Completes, Pléiade, (Gallimard, 1949). 
que franceses e huróes tinham escalas de valor próprias e incomensuráveis, mas de ilustrar a validade; para franceses e huróes, de padróes universais de moralidade, transgredidos pelos franceses, e dos quais os hurōes estavam mais próximos (29).

Todos esses exemplos são fictícios, e íncluo nessa categoria o índio de Montaigne, embora seja um fato histórico que depois da fundação da França Antártica vários indígenas brasileiros foram levados à França. Todos eles são falsos estrangeiros, persas e hurōes de opereta, na verdade máscaras do europeu quando ele se póe em postura auto-reflexiva. São artifícios pela qual a cultura européia assume uma posiçáo de excentricidade com relação a si mesma, vendo-se de fora.

O antropólogo comunicativo herda essas duas formas de descentramento e graças a elas contribui para o descentramento da cultura alheia e da própria.

Na primeira, ela viaja ao estrangeiro. É o sábio de Rousseau. Ele se descentra, assumindo em parte a perspectiva de cultura alheia; ajuda essa cultura a descentrar-se, confrontando-a com uma escala de valores diferente da sua; e favorece a descentraçāo da cultura própria, mostrando o particularismo das suas opiniōes.

$\mathrm{Na}$ segunda, ele se expatria em sua própria casa. $\mathrm{O}$ antropólogo se descentra, transformando-se em estrageiro: É o persa de Montesquieú. $E$ ajuda a descentrar-se a cultura da qual se alienou, submetendo-a a um olhar crítico que a priva de suas ilusóes etnocêntricas.

Com isso, a antropologia comunicativa náo atingiu ainda a meta da reversibilidade, que só poderá ser alcançada quando as duas comunidades forem suficientemente iguais em poder para que qualquer uma delas póssa tomar a iniciativa de estabelecer com a outra um encontro inter-cultural e para que ambas possam ser objetos de saber e de avaliação.

Mas ele pode contribúir para isso estabelecendo relaçōes argumentativas em sua cultura, de modo que também ela, e não apenas a primitiva, seja investigada e julgada. Os dois processos dialógicos se comṕletariam, e a mediaçáo seria dada pelo pólo comum a ambos, o antropólogo, cidadáo dos dois mundos, exilado nos dois, que por não ser mais puramente Ocidental representaria em sua cultura o ponto de vista indígena, e por não poder tornar-se de fato um verdadeiro indígena representaria junto a ele o ponto de vista

(29) Voltaire, Romans đäntes (Gallimard, 1972).

Estudos Avançados, 4(10) 
Ocidental. Descentradas graças aos dois circuitos argumentativos, as duas culturas se aproximariam, porque deixaram de ser estanques uma para a outra.

Estariam assim criadas condições necessárias para a reversibilidade, embora năo sejam condiçóes suficientes, porque a remoção da assimetria estrutural exige medidas políticas que transcendem em parte o âmbito argumentativo.

Quando isso acontecesse, a argumentaçāo cognitiva inter-cultural teria o caráter de um verdadeiro discurso, e năo de um quase-discurso, e a argumentaçáo prática incidiria sobre a estrutura normativa das duas culturas, e não apenas de uma.

Generalizada essa reversibilidade para todos os encontros entre culturas, estaria atingido o grande ideal ético da concepçáo comunicativa: estabelecimento efetivo, e náo somente pressuposto, de uma comunidade argumentativa universal.

\section{VI}

Em resumo, a ética está na origem do saber antropológico, tanto no nível da interação quase-discursiva entre o etnólogo e a outra cultura, como no nível do discurso entre pares.

Está na origem do processo de transformação social induzida: é a ética que leva a antropologia a participar de processos de mudança social, pois é em nome de princípios morais que ela recusa o status quo em certas culturas; é a ética que condiciona uma certa concep̧̧ão de mudança, baseada na autonomia das populaçōes interessadas; é a ética que fornece o quadro para organizar a comunidade argumentativa com fins transformadores, tanto no plano da argumentação em geral como no caso específico da mudaça normativo-institucional.

Enfim, é a ética argumentativa que rege o estabelecimento de processos dialógicos tendo por objeto a cultura Ocidental, e é o ideal ético da reversibilidade plena que impulsiona em direção a uma comunidade argumentativa universal, em que todas as culturas possam se enriquecer com as formas específicas encontradas por cada uma para realizar os valores universais em que se enraíza a comunicação humana.

Vinculada a uma ética universal e visando uma comunicaçáo universal, a antropologia passaria a ser o que Rousseau queria que ela fosse: a science communme des sages.

Copenhague, junho de 1990. 